Mojca Leskovec

DOI: $10.4312 /$ vestnik.11.391-392

Filozofska fakulteta, Univerza v Ljubljani

Slovenija

mojca.leskovec@ff.uni-lj.si

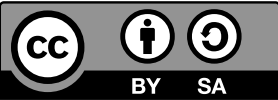

\title{
BRUNO UND ICH: DEUTSCH FÜR KINDER: BAND 1: SCHÜLERBUCH
}

Bruno und ich: Deutsch für Kinder: Band 1: Schülerbuch

Licenčna izdaja dela ich und du neu (2017) poljske založbe PWN Wydawnictwo Skolne avtoric Kozubska, Marta/Krawczyk, Ewa/Zastąpiło, Lucyna (2018): Bruno und ich: Deutsch für Kinder: Band 1: Schülerbuch. Berlin: Cornelsen Verlag. ISBN: 978-3-06120792-2, mehka vezava, 68 strani, 10,99€.

\section{Uvod}

Učno gradivo Bruno und ich 1 poleg pregledanega učbenika, izdanega v letu 2018, ter delovnega zvezka s priloženo avdiozgoščenko obsega še avdioposnetke k učbeniku, digitalni priročnik za učitelja in izročke za pouk. Na platformi Scook (https://www.scook.de/) je prav tako na voljo učbenik v e-obliki. Za osrednjo učbeniško figuro, medvedka Bruna, pa je bila izdelana tudi marioneta.

\section{Zgradba učnega gradiva}

Učbenik kot osnovno učno sredstvo sestavlja dvanajst kratkih enot s po štirimi stranmi in enotno zgradbo: s pomočjo slikovnega gradiva so najprej vpeljane nove besedne zveze in strukture, sledi didaktična igra, nato pa igra vlog, pesem, naloga slušnega razumevanja in miniprojekt. Na zadnjih straneh učbenika najdemo dodatno gradivo za igro in petje, dodatno enoto za spoznavanje prazničnih običajev nemško govorečih dežel in slikovni slovar obravnavanega besedišča. Platnice učbenika ponujajo pregled v učbeniku uporabljenih simbolov in navodil za delo.

\section{Vsebina učnega gradiva}

Dvanajst učbeniških enot, naslovljenih Wer bist du?, slov. Kdo si?, Ich spiele gern, slov. Rad/-a se igram, Meine Spielsachen, slov. Moje igrače, Farben, slov. Barve, Zahlen, slov. Stevila, Ich esse gern Obst, slov. Rad/-a jem sadje, Das trinke ich gern, slov. To 
rad/-a pijem, Mein Haus, slov. Moj dom, Meine Familie, slov. Moja družina, Schulsachen, slov. Šolske potrebščine, In der Schule, slov. V šoli, In der Pause, slov. Med odmorom, posega k temam osebne identitete in odnosov z drugimi, prostega časa in izobraževanja, vsakodnevnega življenja ter hrane in pijače, pri čemer v ospredje postavlja zanimanja ciljne skupine, opredeljene kot otroci v starosti od šest do osem let, ki se z nemščino srečujejo kot s prvim tujim jezikom.

\section{Razvijanje sporazumevalne zmožnosti}

Skladno s ciljno skupino in načeli zgodnjega učenja tujih jezikov je razvijanje receptivnih zmožnosti v učnem gradivu Bruno und ich na vstopni ravni omejeno na urjenje slušnega razumevanja, razvijanje produktivnih zmožnosti pa na urjenje govornega sporočanja in sporazumevanja. Razvijanje specifičnih jezikovnih zmožnosti poteka prek vizualne podpore in s posnemanjem. Učno gradivo pri tem ponuja dovolj jezikovnega vnosa, da učenci v nadaljevanju razvijejo celostno sporazumevalno zmožnost.

\section{Metodično-didaktični pristop}

Učno gradivo Bruno und ich 1 dosledno upošteva načela zgodnjega učenja tujih jezikov. Gradi na poslušanju in razumevanju kot prvem koraku k sporazumevalni zmožnosti. Učenje nemščine kot prvega tujega jezika poteka prek zabavnih vsebin, bogate vizualne podpore, igralnih in gibalnih dejavnosti ter glasbe, s čimer sta uresničeni načeli celostnega učenja in igre. Zaradi kratkotrajne pozornosti ciljne skupine se v enotah izmenjujejo raznolike kratke dejavnosti, ki potekajo v različnih učnih oblikah. Z Brunovim projektom na koncu vsake enote pa se otroci še posebej učijo dela v skupini.

\section{Zaključek}

Ocenjujem, da je gradivo Bruno und ich 1 primerno za prvi stik z nemščino kot tujim jezikom pri začetni formalni obliki učenja v prvi triadi osnovne šole. Učenci s predelanim gradivom razvijejo zmožnost slušnega razumevanja, tako da razumejo pogosto rabljena navodila za delo $\mathrm{v}$ razredu in izbrane podatke $\mathrm{v}$ besedilih $\mathrm{z}$ znano tematiko s pomočjo vizualne opore. Prav tako razvijejo zmožnost govornega sporočanja in sporazumevanja, tako da poimenujejo neposredni svet okoli sebe, se sporazumevajo po vzorcih ter pojejo, recitirajo pesmi in govorijo izštevanke. Vse te razvite spretnosti pa predstavljajo izhodišče za učinkovito nadaljnje učenje nemščine kot tujega jezika. 